\title{
Pawel Dudziak
}

\section{Pan Soplica jako maska pseudonimu Henryka Rzewuskiego ${ }^{1}$}

ABSTRACT. Dudziak Paweł, Pan Soplica jako maska pseudonimu Henryka Rzewuskiego [Pan Soplica as a mask of Henryk Rzewuski's pseudonym]. „Przestrzenie Teorii” 3/4, Poznań 2004, Adam Mickiewicz University Press, pp. 71-85. ISBN 83-232-1454-9. ISSN 1644-6763.

Traditionally spoken genre, which in the 17 th and 18 th centuries was the noblemen's tale, became in the 19th century a written form of tale, i.e. Pamiątki Soplicy [The memoirs of Soplica] of Henryk Rzewuski. The genre description of tale has always presented troubles to literary scholars - an attempt at capturing its distinctive features are usually not very precise or discussed from too many aspects. Studies on the tale should be started from the new recognition of the status of the tale "narrator" in the model realisation of the genre, i.e. Pamiatki Soplicy [The memoirs of Soplica]. The thesis of this article is: narrator - Seweryn Soplica - is Henryk Rzewuski's pseudonym; a pseudonym which allows him to better and more effectively describe the presented, but the already non-existent Sarmatian world of the 18th century.

Nam pozostaje tylko imię -

Cudowny dźwięk na długie czasy².

Mowa [...] jawi się jako teatr, gdzie jednostka, zdejmując kolejne maski, nie potrafi odsłonić swej nagiej twarzy, i gdzie, nakładając maski, nie może nigdy swej twarzy całkowicie ukryć, gdzie widz nie jest pewien, czy widzi twarz, czy maskę, i która $\mathrm{z}$ nich jest prawdziwsza ${ }^{3}$.

Dziewiętnastowieczna gawęda szlachecka to dziwny gatunek literacki prozy narracyjnej, który narodzil się wtedy, kiedy gawęda jako gatunek mowy na zawsze umarła. Gawęda w oryginalnej, oralnej formie odeszła wraz ze śmiercią ostatnich gawędziarzy i ich wdzięcznych słuchaczy XVII-XVIII-wiecznej Polski sarmackiej - utraciła swój naturalny kontekst i została pozbawiona warunkującej jej istnienie sytuacji komunikacyjnej. Gawędziarze nie pozostawili po sobie niczego, ponad pamięć i nieśmiertelną sławę niezrównanych anegdot, które legły u podstaw jej

1 Tekst jest zmodyfikowaną wersją referatu wygłoszonego na konferencji „Przebieranie ja. Kondycja podmiotu w literaturze polskiej XX wieku (i nie tylko)" zorganizowanej w dniach 9-10 III 2003 r. przez Zaklad Literatury Polskiej XX wieku Uniwersytetu Warszawskiego przy współpracy Uniwersytetu im. Adama Mickiewicza w Poznaniu.

${ }^{2}$ O. Mandelsztam, [Nie wierzqc $w$ cuda zmartwychwstania...], w: Poezje, Warszawa 1997, s. 76.

${ }^{3}$ A. Okopień-Sławińska, Semantyka wypowiedzi poetyckiej, Kraków 1998, s. 121. 
gatunkowej, literackiej odmiany. Te literackie narodziny gatunku można datować bardzo precyzyjnie na okres lat 30. XIX stulecia: najpierw w roku 1830 Henryk Rzewuski wygłaszał „swoje” gawędy w sparaliżowanym mrozami Rzymie, rozgrzewając i bawiąc w ten sposób towarzystwo rodaków (w tym Mickiewicza), następnie rozpocząl (za namową Mickiewicza) ich spisywanie, aby wreszcie w 1839 roku w niejasnych dosyć okolicznościach „wydać” większość z nich w Paryżu4. Rozpoczął tym samym modę literacką, nazywaną „boomem sarmackim” lat 30. XIX wieku. To gawędowe szaleństwo doprowadziło w prostej linii do powstania Pana Tadeusza i Trylogii; jego głośne echa rozbrzmiewają również w Gombrowiczowskim Trans-Atlantyku, by wymienić narracje powszechnie kwalifikowane jako gawędowe. Rzewuski stał się teoretykiem-praktykiem, ojcem-prawodawcą silnego, płodnego w realizacje, odpornego na zmiany epokowe, tworzącego XIX-wieczną świadomość literacką nurtu kulturowego zwanego „sarmatyzmem literackim"5 dla oznaczenia jego gawędowego, fikcyjnego, literackiego pochodzenia.

Chciałbym uczynić przypis do Pamiątek Soplicy Henryka Rzewuskiego. Zanim to jednak zrobię, jedno więcej wyjaśnienie - będzie to raczej przypis do nie istniejącego jeszcze tekstu definicji gatunku gawędy ${ }^{6}$. Co prawda nie istnieje zadowalająca definicja, ale istnieją próby stworzenia tejże. (Być może powstanie ona na marginesie rozważań takich jak te). Dodajmy, iż ważny problem statusu podmiotu w literackiej gawędzie sarmackiej nie został dotychczas dostrzeżony i opisany.

Pan Soplica jest nie tyle maska, ile maskq pseudonimu Henryka Rzewuskiego. Maska zakłada zawsze zmianę tożsamości, a nakładający maskę, chowający się za/pod maską nie tylko wygląda jak ktoś inny, ale przede wszystkim wchodzi w posiadanie innego, obcego mu języka, a więc mówi nie za/od siebie, staje się nie-sobą. Maska ukrywa, pokrywa twarz podmiotu nieprzenikalną warstwą ochronną. Pozwala jednocześnie zniknąć i pojawić się $\mathrm{w}$ tej samej chwili pod nierozpoznawalną formą. Po to przebrał się, zakładając maskę dandysa, Juliusz Słowacki. Jak pisał w liście do matki:

Dziś udała mi się moja rola w ogrodzie Tuileries: po raz pierwszy ubiorem zwróciłem oczy dam [...]. Jeden z moich kolegów usłyszał damę mówiącą: „Jaki ładny

${ }^{4}$ Wedle późniejszych zapewnień Rzewuskiego, zostały one wydane bez jego wiedzy i zgody. Kwestię, na ile wiarygodne jest to, co mówił on na temat swojej twórczości, pozostawiam w tym miejscu otwartą.

5 Terminu „sarmatyzm literacki” używam dla opisu XIX-wiecznego zjawiska boomu sarmackiego od połowy lat 30., czyli fascynacji kulturą szlachecką XVII i XVIII wieku. Dla historycznego okresu w dziejach Polski XVII i XVIII wieku zarezerwowane pozostaje pojęcie „sarmatyzmu formacyjnego".

${ }^{6} \mathrm{O}$ gawędzie pisano i mówiono wielokrotnie, ale zawsze krótko, okazjonalnie bądź świadomie aspektowo. 
kostium". [...] Otóż teraz z rana jestem literatem [...], a wieczorem staję się dandysem, angielskim modnisiem [...]; staram się, żeby nikt wieczorem nie odgadł, czym ja jestem $\mathrm{z}$ rana - a z rana, żeby nic z wieczornej próżności nie zostało. Nie zawsze mi się to jednak udaje... ${ }^{7}$.

Słowacki stroi się nie tylko przeciwko Mickiewiczowi („nie chcę, żeby mię tak jak Mickiewicza do domu gry nie wpuszczano"8), ale też by ukryć prawdziwą (wedle swojego rozeznania) naturę - polskim poetą wszakże nie przestal być nigdy, a tylko swoimi talentami aktorskimi zwodził paryskie towarzystwo. Dzięki masce Słowacki ukrył się i stał się taki, jak inni. Jak pisze Gaston Bachelard:

Maska zdaje się zapewniać natychmiastowe ukrycie. Schowany za swoją maską, zamaskowany człowiek [...] szybko uzyskuje poczucie bezpieczeństwa, jakie daje zamknięta twarz. [...] Ukrywszy się, sądzi, że skutecznie udaje. Jest więc maska prostą syntezą dwu bardzo bliskich przeciwieństw: dysymulacji i symulacji. [...] Fenomenologia dysymulacji musi sięgać do źródeł bycia kimś innym ${ }^{9}$.

Maska jest synonimem obojętności - zakładając ją, ja, które dla siebie istnieje jako samotożsame, pragnie ukryć tę własną identyczność przed innym, chce przestać istnieć, pragnie stać się niewidzialne, zobojętnieć dla świata ${ }^{10}$. Warto pamiętać przy tym, że pseudonim również bywa maską - maską tchórzy chociażby. Tak działo się nader często nie tylko w naszych czasach, ale również w czasach Rzewuskiego. On sam przybrał taką maskę Jarosza Bejły, kiedy pisał paszkwilanckie Mieszaniny obyczajowe.

Pseudonim natomiast jest tylko tezą, a więc zaistniałą potencjalnością pozbawioną antytezy w postaci „prawdziwej” twarzy. Osoba pod pseudonimem nie jest dwulicowa, bo nie podlega prawom de/re-konstrukcji; bez pseudonimu w ogóle nie byłaby do pomyślenia jako osoba. Pseudonim jest jedyną, a co za tym idzie, prawdziwą twarzą podmiotu:

Greckie słowo hypostasis tłumaczone było na łacinę jako persona. Wyraz ten, wywodząc się z greckiego prosopon, odpowiadał masce (i to znaczenie spychano w cień, gdyż osoba równałaby się masce, a jak wiadomo, maskę można zmieniać dowolną liczbę razy), lub twarzy (i to znaczenie wybierano najczęściej) ${ }^{11}$.

Soplica byłby zatem personą $\mathrm{w}$ drugim, bardziej pospolitym tego słowa rozumieniu.

${ }^{7}$ Listy Juliusza Słowackiego z 7 marca i 12 lipca 1832 roku.

${ }^{8}$ List z 12 lipca 1832 roku.

${ }^{9}$ G. Bachelard, [Fenomenologia maski], w: Transgresje 4: Maski, t. 2, Gdańsk 1986 , s. 14.

10 G. Bachelard, s. 16.

11 M. P. Markowski, Pragnienie obecności, Gdańsk 1999, s. 74.

73 Pan Soplica jako maska pseudonimu Henryka Rzewuskiego 
Jednocześnie referent tak pojętego pseudonimu nie istnieje w świecie jako obiekt; jest tylko signifié pozbawionym swojego signifiant. Tworzy swoją własną rzeczywistość alternatywną, niesprzeczną jednak $\mathrm{z}$ rzeczywistością imienia. Pseudonim to przede wszystkim s(t)ymulant i kreator, którego moc twórcza kończy się wraz z aktem dysymulacji i syntezy. Inaczej niż w przypadku maski, która domaga się interpretacyjnej de-maskacji, użytkownicy pseudonimu - zarówno jego autorzy, jak i interpretatorzy - powinni chronić go przed de-nominacją. „Zapseudonimowany", czyli zmyślony w piśmie świat sarmacki XVIII wieku, stworzony w XIX wieku m.in. przez Rzewuskiego, uległby rozpadowi i okazałby się absurdalny, gdyby postawić go przed trybunałem „prawdziwej” historii; zniszczyłaby go jakakolwiek weryfikacja czy próba odnalezienia jego „prawdziwego” imienia, próba oddzielenia prawdy od zmyślenia. Pomimo że za pseudonimem nie kryje się nic cielesnego, do jego unicestwienia wystarczy zaledwie gest sprzeciwu, sceptycyzm albo - co najgorsze - nieprzyzwoita ciekawość.

Kiedy mówię o Rzewuskim-Soplicy, myślę o pseudonimie subtelnej proweniencji kierkegaardowskiej. Seweryn Soplica to w sposób oczywisty bowiem twór Rzewuskiego, stworzony nie na potrzeby czytelników ani widzów, nie po to, by ich okłamywać, bawić czy uwodzić. Seweryn Soplica to egzystencjalna, a nie tylko pisarska persona Henryka Rzewuskiego, umożliwiająca mu zrozumienie, a raczej afirmację rzeczywistości sarmackiej i wtopienie się w świat końca XVII i początków XVIII wieku. Uciekając się do metafor, można powiedzieć, że cześnik parnawski został "wynajęty" przez Rzewuskiego do spełniania gawędowego dzieła ${ }^{12}$, że hrabia pożyczył sobie od Soplicy pióro'13. Inaczej niż przyjęło się uważać, Pamiqtki Soplicy to wcale nie literacki bal maskowy, żaden teatr mowy, retoryczny fajerwerk ani konkurs recytatorski - to raczej dramatyczny, wewnętrzny dialog pisarza, poszukującego języka i sposobu na opowiedzenie tego wszystkiego, co miało już na zawsze zostać przez historię skazane na zapomnienie; to próba wydarcia umarłym ich języków gwałt dokonany na przeznaczeniu za pośrednictwem pseudonimu.

Pomimo że Søren Kierkegaard przez całe życie bronił swoich skrupulatnie konstruowanych pseudonimów, to użytkownicy jego pism brutalnie go zlekceważyli (jak się okazuje bowiem, ironia jest nie do zniesienia dla wielu $z$ nas). Może więc nie warto krzywdzić w ten sam sposób Henryka Rzewuskiego i zacząć mówić wprost, że autorem Pamiątek Soplicy jest, jak sugeruje sam tytuł, Seweryn Soplica. Byłoby to postępo-

${ }_{12}$ M. Maciejewski, Gawęda jako slowo przedstawione. $Z$ zagadnień teorii gatunku, w: Poetyka, gatunek, obraz. W kregu poezji romantycznej, Warszawa 1977, s. 114.

13 M. Żmigrodzka, Palestrant, karmazyn i wiek XIX, [Wstęp do:] H. Rzewuski, Pamiqutki Soplicy, Warszawa 1961, s. 23. 
wanie zgodne $\mathrm{z}$ wolą Rzewuskiego ${ }^{14}$ i wbrew jego obawom - panicznie przecież odżegnywał się od tej książki; być może pozwoliłoby to lepiej zrozumieć specyfikę jedynego w swoim rodzaju wydarzenia literackiego XIX wieku. Tożsamość, jak się zdaje, to jedyne, o czym na gruncie badań literackich powinniśmy pozwolić decydować samemu pisarzowi.

Aby lepiej zrozumieć Pamiątki, można również posłużyć się kierkegaardowską formulą, którą filozof interpretowal swoją działalność pseudonimową: oszukujac, zwabić ku prawdzie (przy czym słowo oszustwo należy rozumieć jako symulacje [czyt. tezę] prawdy15). Symulacja dobrze oddaje ducha pseudonimu, bo zakłada prawdę i fałsz w jednym momencie. Na pytanie zadane symulacji, czy istnieje, nie ma dobrej odpowiedzi. Rzewuski swoją „pisaną mową" symuluje mowę żywą, poza tym mówi niby to za siebie, niby za bohatera, pisze literaturę (tj. Pamiątki), którą zdradza $^{16}$ na rzecz historycznego, skrupulatnego dyskursu naukowego (tzn. Uwag o dawnej Polsce). Po co „kłamał” (symulował)? Dlaczego nie mógł powiedzieć wszystkiego „wprost” (syntetycznie)? Krótko mówiąc: po co był Rzewuskiemu pseudonim - konstrukcja trudna w tak mistrzowskiej realizacji, skomplikowana, ryzykowna $\mathbf{i}$ bardzo wyrafinowana intelektualnie? Notabene - nigdy dotąd nie uważano Pamiqtek za dzieło erudycji, ciężkiej pracy i wielu przemyśleń. Jakże niesłusznie... Po co więc pseudonim?

Po pierwsze - co wydaje się oczywiste - nie jest obojętne, z jakiej pozycji i z jakiego miejsca się przemawia: kim się jest dla innych, jakim autorytetem można się przed nimi pochwalić, w jakich układach społecznych i personalnych się pozostaje, jaki strój się nosi, jak głośno i z kogo można się śmiać. Rzutuje to na konstrukcję całości świata przedstawionego, jak twierdzi bowiem Aleksandra Okopień-Sławińska,

układ i rodzaj relacji [osobowych] zależą od socjalnego usytuowania mówiącego ja. Wiadomo, że wybór ja rozstrzyga o przydziale ról dla innych postaci, [które] kreowane zostają przez akt mowy podmiotu. Ważne jest jednak i to, jak ja usto-

14 Istnieje nigdy nie opublikowana przedmowa do Pamiqtek Soplicy, w której Rzewuski sugeruje, że ich autorem jest Seweryn Soplica.

15 „Autor gawędy szlacheckiej podporządkowuje się swoistemu weryzmowi” [M. Maciejewski, Gawęda..., s. 108]; „W Pamiqutkach mamy do czynienia z tą odmianą literackości, którą można nazwać autentyzmem" (K. Bartoszyński, O amorfizmie gawędy, w: Prace o literaturze i teatrze ofiarowane Z. Szweykowskiemu, Warszawa 1966, s. 103); „Na tle calości dzieła stanowi ta postawa narratora symulację artystyczną" (Z. Sz mydtowa, Czynniki gawędowe $w$ poezji Mickiewicza, w: Rousseau - Mickiewicz i inne studia, Warszawa 1961, s. 316).

16 Tę literacką zdradę intuicyjnie opisała Maria Żmigrodzka, kiedy zastanawiała się nad sensownością amorficznej formy Pamiątek Soplicy: „Obraz przeszłości porządnie ułożony przez palestranta byłby płaską pedantyczną ramotą". To spostrzeżenie można z powodzeniem odnieść do Uwag o dawnej Polsce. [M. Żmigrodzka, Palestrant..., s. 9, 26.] 
sunkowuje się w kategoriach socjalnych do innych postaci, z którymi postaciami się utożsamia, które aprobuje, jako rzecznik których się przedstawia, od których zaś się dystansuje, którym się sprzeciwia, uważając za wrogie czy obce, nad którymi ma przewagę, a wobec których czuje się kimś gorszym czy słabszym. W zależności od tego mówiący grupuje objęte horyzontem wypowiedzi towarzystwo w pewne zespoły, w stosunku do których deklaruje swoją wspólnotę lub objawia dystans ${ }^{17}$.

Od tego więc, na jakie imię zdecyduje się podmiot, zależy nie tylko to, co będzie mógł on powiedzieć, ale również kto zechce go wysłuchać. Na rangę, jaką imię odgrywa w gawędzie, zwrócił też uwagę Kazimierz Bartoszyński, dla którego jest ono symulakrum:

Centralnym zabiegiem artystycznym jest wprowadzenie określonej postaci narratora, stanowiącej na zasadzie historycznej „prawdziwości” argument przemawiający za autentycznością pamiętnikarskiej czy gawędowej relacji18.

Tylko Seweryn Soplica zatem mógł być wiarygodnym przewodnikiem po hermetycznych salonach sarmatopola ${ }^{19}$; tylko "wynajmując" Soplicę wraz z jego wyglądem, językiem, poglądami, systemem zachowań i przede wszystkim układami towarzyskimi, mógł Rzewuski namalować dający efekt prawdziwości obraz epoki; tylko Soplica mógł wiarygodnie posłużyć się mową akceptowalną przez świat sarmacki i tylko z Soplicą osobistości tamtego, zmyślonego przecież, świata były się w stanie porozumieć. Pseudonim zatem to "nie tylko odbicie socjalnych układów i stratyfikacji, ale również dana dzięki językowi sposobność do projektowania, formowania i sankcjonowania społecznych sytuacji komunikacyjnych"20.

Po drugie, „inne-moje” imię pozwala mówić „innym-moim” językiem, a więc w konsekwencji powiedzieć coś zupełnie innego, na co w innych okolicznościach (bo pseudonim to zazwyczaj literatura okolicznościowa o czym za chwilę) nie byłoby mnie-pisarza stać; zmiana języka to zmiana światopoglądu - to-samo opowiedziane innymi słowy nie może pozostać toż-samym. Ważną cechą pseudonimu, jak go tutaj rozumiem, jest jego odpowiedzialność za to, co mówi, ponieważ w istocie pozostaje on ciągle autorem ze wszystkimi konsekwencjami tego stanu rzeczy. Przy tym pseudonim "Soplica” bierze odpowiedzialność za "swoje” imię (to on jest „autorem"), a nie za imię Rzewuskiego, który z Pamiq̨tkami Soplicy ma niewiele wspólnego, co starał się udowodnić zaraz po ich wydaniu. Chociaż „pseudonim bywa ironistą, humorystą, eksperymentatorem, teoretykiem, obserwatorem", to jednak ironia pseudonimu nie ma twarzy bła-

17 A. Okopień-Sławińska, op. cit., s. 68.

${ }^{18}$ K. Bartos zyński, O powieściach Fryderyka Skarbka, Warszawa 1963, s. 245.

19 "Gawędopole" to określenie autorstwa Jana Śniadeckiego.

${ }^{20} \mathrm{~A}$. Okopień-Sławińska, op. cit., s. 97. Podkreślenie moje. 
zeńskiej, bo „angażuje się on w opisywane doświadczenie”21 i zazwyczaj traktuje je poważnie. Powaga ta wynikać może z tego również, że dla pseudonimu czas trwania jego opowieści jest jedynym czasem, jaki został mu podarowany - pseudonim, który kończy mówić, znika ze sceny swego tymczasowego żywota, zostaje szybko zapomniany. Bohater, którym pragnie być pseudonim, nie może stracić głosu (,[...] i głosu nie stracił bohater" - pisał Homer). Aby nie stracić głosu i nie popaść tym samym w zapomnienie, gawędziarz Soplica będzie gawędził, kluczył, zmyślał i przypominał sobie - byle tylko mówić zajmująco, byle tylko uratować swoje imię swoją opowieścią. Dlatego właśnie w gawędzie akt mówienia jest równie ważny, jeśli nie ważniejszy, od aktu opowiadania. Mówienie „innym-moim” głosem jest wydarzeniem doniosłym, w przypadku $P a$ miq̨tek wręcz egzystencjalnym. Po zdjętej z twarzy masce pozostaje maska - po „zdjętym” pseudonimie nie pozostaje nic.

Po trzecie, pseudonim jest na tyle integralną częścią dzieła, że musi być interpretowany na równi z samym dziełem. Co ważne: wymyka się on jałowym, jeżeli nie zgubnym, zabiegom biograficznym, oddając się czysto literackiej analizie.

Pisząc o Kierkegaardzie, Alina Djakowska stworzyła opis, który nader celnie charakteryzuje sytuację Seweryna Soplicy:

Kim jest pseudonim? Może mieć swój zawód, może być np. pustelnikiem lub asesorem. Jest automiczny: wymyśla wlasne imię, temat, metodę i tytuł dzieła. [...] Pseudonim nie jest dekoracją, ponieważ jest eksperymentem, pewną formą badania i poznania. Ta forma stanowi integralną część przesłania ${ }^{22}$.

Czym więcej jest Seweryn Soplica niż fragmentem tytułu znacząco umieszczonym w dopełniaczu? Być może, jak twierdzi Sokrates w Kratylosie, imię jest ,jak cała wypowiedź”?23

Po czwarte wreszcie, dla Rzewuskiego pseudonim jest zatrzymanym marzeniem o bezpowrotnie utraconym, egzotycznym świecie sarmackim, z którego romantyzm uczynił nie tylko kolebkę polskości, ale też nostalgiczny przedmiot westchnień. Interpretacja pseudonimu powinna zatem być bliska interpretacji marzeń. Mówiąc inaczej: pseudonim dla Rzewuskiego to manifestacja i zarazem sposób na nostalgię, jako że „pseudonimy okresu romantyzmu sprawiają wrażenie amuletów dźwiękowych"24, które brzmieniem przywolują to, co nieobecne. Kryje się w pseudonimie

${ }^{21}$ A. Djakowska, Jestem Pseudonimem, „Principia” XXIII (1999): Tożsamości Kierkegaarda, Kraków 1999, s. 83.

22 A. Djakowska, s. 82, 86. Podkreślenie moje.

${ }^{23}$ R. Przybylski, Mityczna przestrzeń naszych uczuć, Warszawa 2002, s. 100.

${ }^{24}$ D. Swierczyńska, Pseudonimy, w: Stownik literatury polskiej XIX wieku, Wrocław 2002, s. 807 . 
Soplicy „metafizyka nieobecności”, a więc rodzaj pragnienia, ale i wiara w to, czego nie ma.

W jednym $\mathrm{z}$ listów do żony Rzewuski opisuje, banalne pozornie, a ze względu na przyszłe losy jego imienia, zadziwiające zdarzenie:

Księcia [Eustachego - P.D.] niewiele znalazłem zmienionym, jest coś w nim niezmiernie żywotnego [...], cztery doby z nim przepędzilem, jest to ostatni magnat dawnego typu naszego, a co dziwne, pokąd żyl Książę wojewoda [Karol Radziwill „Panie Kochanku” - P.D.], nic nie był do niego podobny, a on wykapany. Możesz sobie wystawić, co to była za gawęda, oba ciągle byliśmy na nogach. [...] Razu jednego [...] pokazał mi dom źółty [...] naprzeciwko pałacu, ale ten dom już wgrzęźnięty w ziemię [...], i pyta mnie, czy wiem, co to za dom - nie wiem mości Książę - dom stary, [widzicie], a ja go nie zrzucam, bo w nim się rodzil Seweryn Soplica Cześnik Parnawski. I tak jest w samej istocie. [...] Ze łzami opuściłem tą świątynię naszych drogich pamiątek, bo on byl przyjacielem mojego dziada i ojca $[. . .]^{25}$.

Taka jest (jedna z możliwych) geneza pseudonimu Henryka Rzewuskiego. Soplica to - podobnie jak gawęda w całości - pamiątka po tym, co minęło i istnieje tylko w sentymentalnych ruinach. Trzeba przyznać, że Mickiewicz poza znakomitą intuicją do potencjalnych arcydzieł, mial też dobre ucho - usłyszał ukrywającego się w imieniu Soplicy „ducha narodu" i nazwał Soplicowem krainę, którą powołał do istnienia w Panu Tadeuszu. Soplicowo to przecież miejsce, którego nie ma, a które uznawane jest za prawdziwe mocą narodowej woli i tęsknoty.

Pseudonim to jednak nie tylko forma rozmarzenia się podmiotu, ale też skuteczny sposób na stworzenie mitologii. Jak pisze Borys Uspienski - sama nominacja jest naturalną cechą świata mitologicznego:

Pewne sytuacje fabularne $[\ldots]$ sprawiają, że nazywanie rzeczy, które nie mają nazwy, traktuje się jako akt stworzenia, przemianowanie zaś - jako przeistoczenie albo nowe narodziny. [...] Właśnie w sferze nazw własnych następuje to utożsamienie słowa i denotatu, które jest charakterystyczne dla wydarzeń mitologicznych ${ }^{26}$.

Przemianowanie to inne określenie pseudonimu. Pseudonimując swoje imię, podmiot dokonuje „obrzędu nominacji”, zaklina siebie, ale przede wszystkim to, na co spogląda swoim nowo narodzonym okiem - to ono jest stawką gry $\mathrm{z}$ imieniem własnym. Komentujący Uspienskiego

${ }^{25}$ Listy Henryka Rzewuskiego do żony Julii $z$ Grocholskich. Rękopis BJ 5996/II (mf BN 24917). Podkreślenie moje. Dziękuję Bartłomiejowi Szleszyńskiemu za informację o tym liście oraz udostępnienie mi jego kserokopii.

${ }^{26}$ B. Uspienski, Mit - imię - kultura, w: Historia i semiotyka, Gdańsk 1998. Cyt. za R. Przybylski, op. cit., s. 100. 
Ryszard Przybylski dodaje: „Nazwa pospolita jest słowem widmowym. Inaczej jest $\mathrm{z}$ nazwą własną, nawet wówczas, kiedy nie jest jednoznaczna"27. Henryk Rzewuski jest właśnie taką „nazwą pospolitą" - dla świata sarmackiego pustą, abstrakcyjną i w żaden sposób nie przystającą do jego realiów. Seweryn Soplica to jego jedyna szansa na poznanie nieznanego; to sarmackie okulary, przez które może oglądać kłębiące się wszędzie wokół widma staro-Polski.

Nie warto lekceważyć również innych możliwych przyczyn zmiany imienia przez Rzewuskiego. Seweryn Soplica mógł być przecież ukryciem przed cenzurą (zarówno towarzyską, jak polityczną), mógł być elementem rodzącego się romantycznego nurtu poetyzowania historii czy też, stanowić modny zabieg jej mistyfikowania poprzez pisanie/fałszowanie autentycznych zabytków językowych (czego dobrym przykładem są Reszty pamiętników Michala Rogowskiego rotmistrza konfederacji barskiej, czyli wydane anonimowo gawędy autorstwa Konstantego Gaszyńskiego ${ }^{28}$ ).

O drugim imieniu Rzewuskiego można też opowiedzieć w kategoriach klasycznej teorii literatury, która uczy, że każde ja użyte w jakimkolwiek tekście zawsze już jest pozbawione podmiotowości, zawsze już jest $j a$ uprzedmiotowionym. Nawet gdyby Rzewuski wprost mówił $j a$, i tak byłby przedmiotem swojej własnej wypowiedzi. A więc z punktu widzenia teorii komunikacji, uprzedmiotowienie Soplicy nie jest niczym aż tak wyjątkowym i rewolucyjnym, jak wielu badaczy jest skłonnych przypuszczać - to po prostu transpozycja osobowa znana pod nazwą pseudonimu. Jak każda transpozycja, ujawnia się ona na poziomie tekstowych niedopasowań, napięć i paradoksalności, które zaburzają standardowy układ relacji osobowych. Jest to jednocześnie figura nie domagająca się rozwikłania i hipotetycznego przywrócenia stanu normalności komunikacyjnej. Rozumienie transpozycji nie polega na unieważnieniu jej działania, ale na koniecznym zinterpretowaniu komplikacji, jakie ze sobą niesie:

Transpozycja [...] jest [...] rodzajem gramatycznej metafory pomnażającej semantyczny potencjał wypowiedzi. Mechanizm jej działania polega zawsze na zwielokrotnieniu znaczenia zastosowanej formy [...]. Zabieg ten pozwala niepomiernie wzbogacić socjalno-towarzyską charakterystykę relacji osobowych, wprowadzając szereg informacji na temat powikłań, niuansów i rozmaitych perspektyw w nastawieniu mówiącego wobec siebie i innych ${ }^{29}$.

${ }^{27}$ R. Przybylski, op. cit., s. 100.

28 Warto zwrócić uwagę na „pseudonimową" zbieżność konstrukcji tytułów Pamiq̨tek i Resztek.

${ }^{29}$ A. Okopień-Sławińska, op. cit., s. 76-77. 
Czy zatem należy badać i rekonstruować poglądy Soplicy, aby triumfalnie stwierdzić, że nie pasują w całości do postaci Rzewuskiego? Wydaje się, że receptą na tę niefortunną, a utrwaloną w badaniach literackich metodę może okazać się pseudonim. Bo oczywiste jest (przynajmniej dla uważnych czytelników Constantina Constantinusa), że pseudonimu nie powinno się zbyt lekkomyślnie demaskować - wówczas niszczy się niezwykly, ale kruchy związek pomiędzy dwoma imionami (toż)samości:

Relacje [pomiędzy ludźmi], które się zawiązuje, które się splata, które nakładają się na siebie, muszą być skomplikowane, a jako takie nie dają się eksplikować, to znaczy rozkładać, rozplątywać, rozwarstwiać lub - jak często mówimy - wyjaśniaćc ${ }^{30}$.

Zadziwiająco trafnie i $\mathrm{z}$ intuicją pisze o zapseudonimowanym autorstwie Pamiqtek Soplicy Dobrosława Swierczyńska. Dla badaczki (trudno uwierzyć: pseudonimu, a nie twórczości Rzewuskiego!) jest oczywiste, że Seweryna Soplicę należy uznać za pseudonim Rzewuskiego. Przywołując opinię o swoistym realizmie utworu, dodaje, iż

realizm ów jest wynikiem mistrzostwa w ukształtowaniu narratora, mistrzostwa wzmocnionego jeszcze wysunięciem Soplicy na pozycję "autora" na karcie tytułowej ${ }^{31}$.

Autorka stawia jednocześnie dwa bardzo ważne pytania: czy element tytułu można traktować jako pseudonim twórcy oraz co pozwala uznać Soplicę za pseudonim Rzewuskiego, skoro on sam tego pseudonimu nie potwierdził. Z tego teoretycznego impasu Swierczyńska wychodzi przywolując kontekst historycznoliteracki, czyli historyczno-historiozoficzny traktat Rzewuskiego pod iście sarmackim tytułem Uwagi o dawnej Polsce przez starego Szlachcica Seweryna Soplicę Cześnika Parnawskiego napisane 1832 roku $^{32}$, w którego tytule bezpośrednio pojawia się przyimek „przez”, bezsprzecznie, zdaniem badaczki, zaświadczający o autorstwie Soplicy. W przypadku Uwag o dawnej Polsce

autorsko-pseudonimowa funkcja "Seweryna Soplicy" nie wzbudzi niczyich wątpliwości dzięki przyimkowi „przez” poprzedzającemu w XIX-wiecznym edytorstwie zazwyczaj nazwisko autora ${ }^{33}$.

${ }^{30}$ M. P. Markowski, Pragnienie i balwochwalstwo, Kraków 2004, s. 33.

31 D. Swierczyńska, Polski pseudonim literacki, Warszawa 1999, s. 151. Podkreślenie moje.

32 Uwagi o dawnej Polsce przez starego Szlachcica Seweryna Soplicę Cześnika Parnawskiego napisane 1832 roku. Rękopis niewydany rękq Henryka Rzewuskiego, opracowali i przygotowali P. Dudziak i B. Szleszyński, Warszawa 2003.

${ }^{33}$ D. Swierczyńska, Polski pseudonim..., s. 151. 
Autorka na podstawie analizy i porównania samych tylko tytułów wyciąga wniosek, że Soplica jest pseudonimem Rzewuskiego. Tę słuszną, aczkolwiek intuicyjną tezę, potwierdzają intencje i ustalenia wydawców Uwag o dawnej Polsce, którym zależało przede wszystkim na rozszerzeniu kontekstu badań Pamiqutek Soplicy i statusu samego Seweryna Soplicy. Uwagi mają więc tego samego "tytułowego autora”, a mianowicie Seweryna Soplicę, i tego samego „bohatera przedstawionego”, czyli świat sarmacki. Nie byłoby to aż tak niezwykłe, gdyby nie fakt, że tym razem Soplica nie okazal się zacofanym i ograniczonym umysłowo szlachciurą, ale historykiem, erudytą i (na ile potrafił) sumiennym kronikarzem. Tym razem nie zabawił swoich słuchaczy anegdotami, nie porwał bogactwem i kuglarstwem swojego języka - był spokojny, bywał (na swój sposób) rzeczowy, a nawet nudny. Seweryn Soplica okazał się kimś, kto panuje nad swoim mówieniem i kto wie, co mówi. Porównanie obu, pisanych w zupełnie innej poetyce tekstów dowodzi bowiem, że poglądy wyrażane w nich są nie tylko jednakowe, ale nawet wprost literalnie zbieżne ${ }^{34}$. Wiele wskazuje na to, że Rzewuski pisał Pamiątki i Uwagi równolegle, traktując je jako teoretyczną podstawę swojej prozy, a nawet jako poligon gawędowej teorii. Uwagi o dawnej Polsce są więc świadectwem drogi, którą odbył Rzewuski-Soplica pracujący nad ostateczną wersją zbioru swoich gawęd. Okazuje się, że gawędy, które dotychczas uważane były za romantycznie natchnione i „pisane z rękawa”, są efektem długotrwalych studiów historycznych; studiów szczęśliwie utrwalonych na piśmie. Recenzenci Uwag, Kazimierz Bartoszyński i Janusz Tazbir, nie mieli wątpliwości, że uznać je należy za traktat z zakresu historii ustroju czy też historii prawa, w którym nie może być mowy o literackiej grze dystansu. "Tytułowy autor" nie był - warto przypomnieć - literacką ozdobą ani komercyjnym, koniunkturalnym wabikiem, ale poważnym pseudonimem nie ograniczonym, co się zbyt często sugeruje, niewielkimi możliwościami umysłu ani ciasnym światopoglądem.

Jednocześnie z samego faktu, że „autor" Uwag miał do badanej epoki stosunek poważny, nie trzeba koniecznie wnioskować, że musiał to być stosunek krytyczny. To istotny wniosek, gdyż dotychczas wszyscy bada-

${ }^{34}$ Dokonana przez Dudziaka-Szleszyńskiego szczegółowa analiza porównawcza fragmentów Pamiqtek Soplicy oraz Uwag o dawnej Polsce jest niemożliwa do przywołania, a choćby streszczenia $w$ tym miejscu. Za dowód niech posłuży przykładowe zestawienie, jakiego w swoich analizach dokonał Bartłomiej Szleszyński: „Bywały przykłady, ze bez pomocy nawet familijnej sam winowajca podawał dobrowolnie głowę pod miecz, woląc umrzeć obywatelem niż ochraniając nędznego żywota, który i tak wiecznie trwać nie będzie - żyć w niesławie” (Pamiątki Soplicy, Warszawa 1983, s. 170); „Obywatel osądzony wywołany, pozbawiony wszelkich praw jego stanowi służących, sam spieszył wykonać wolę prawa, aby koniec polożyć i zgryzotom sumienia i stanowi gorszemu od samej śmierci" [...] (Uwagi, s. 111). 
cze zgodnie twierdzili, iż obraz Polski zawarty w Pamiątkach jest, po pierwsze, wyidealizowany, a po drugie, niezupełnie serio; że autor gawęd (Rzewuski), posługując się zręczną ironią, chciał wytknąć wady tamtego systemu. Najwyraźniej jednak nie taka była intencja autorska - Soplica nie jest tak obcy Rzewuskiemu, jak przyjęło się twierdzić, a skoro pseudonim nie krytykuje, nie można o to podejrzewać również jego twórcy. Przeciwnie: wyidealizowany obraz Polski nie jest efektem literackiej kreacji (tzn. niskiego poziomu intelektu Soplicy), ale poglądów Henryka Rzewuskiego, który również w Uwagach tworzy obraz Sarmacji zbudowany na drobnych przemilczeniach. Nie miał najwyraźniej ochoty odprawiać sądu, a choćby mówić o wadach XVII/XVIII-wiecznej Polski. Tego wszystkiego uczy skrupulatna lektura Uwag. Również tego, że Soplica nie jest wytworem fantazji Henryka Rzewuskiego, ale jego imieniem własnym. Imieniem czy pastiszem imienia? „Autor [...] nie może utożsamiać się z opowiadaczem i twórcą tekstu gawędowego. Trzeba posłużyć się pastiszem"35, albo jak mówi Marian Maciejewski w innym miejscu: „maską pastiszu” 36 , bo gawęda „W swej całości zawsze będzie bardziej pastiszem niż stylizacją"37. Czy działalność pseudonimowania można określić mianem pastiszu? Pozostając przy zakresie znaczeniowym proponowanym przez Stownik terminów literackich ${ }^{38}$, z całą pewnością nie. Jeśli natomiast uznać pastisz za twórczą próbę przejęcia podstawowych cech wypowiedzi Innego, wynikającą $\mathrm{z}$ wiary podmiotu mówiącego w językowy charakter poznania świata (,głos bowiem nawet bardziej niż wierny obraz czy dagerotyp daje nam materialny, zmysłowo uchwytny kontakt $z$ nieobecną osobą"39), to pseudonim jest zdarzeniem w obrębie pastiszu.

Podsumowując: Seweryn Soplica to autor Pamiatek Soplicy. Takie historyczne sprostowanie tłumaczy wiele, m.in. sławę, jaką się ten zbiór gawęd cieszy(ł). To dlatego tak one porwały czytelników, dlatego stały się swego czasu wręcz epopeją narodową i książką, w której zagnieździła się polskość, że opowiadal je rasowy szlachcic i gawędziarz Seweryn Soplica. Tak się bowiem złożyło, że nikt nie słuchał i nie słucha do dziś

${ }^{35}$ M. Maciejewski, Gawęda..., s. 108.

36 Tamże, s. 103.

37 Tamże, s. 109.

38 „Pastisz - odmiana stylizacji: utwór powstały w wyniku świadomego podrabiania maniery stylistycznej konkretnego dzieła, autora, czy szkoły literackiej; polega na celowym wyostrzeniu cech znamiennych naśladowanego sposobu wypowiadania się, który dzięki temu ukazuje się $w$ postaci ostentacyjnie wyrazistej. Pastisz uprawiany bywa w zamiarach zartobliwych lub jako forma krytycznoliterackiej penetracji cudzego stylu". Stownik terminów literackich, red. J. Sławiński, Ossolineum 1998, s. 376.

${ }^{39}$ M. Maciejewski, Gawęda o gawędzie Panie Kochanku, w: Choć Radziwitt, alem człowiek..., Kraków 1985, s. 38. 
Henryka Rzewuskiego, o którym mówi się różnie - najczęściej źle i najczęściej słusznie. Pamiątki jednak zawsze żyły i żyją poza tą podłą legendą, jakby nie były utożsamiane $\mathrm{z}$ Rzewuskim. Oto prawdziwa siła, sens i sukces pseudonimu...

Warto przytoczyć anegdotę dotyczącą pierwszej edycji Pamiątek, które nie były oznaczone imieniem Henryk Rzewuski. Większość recenzentów pisała wówczas o panu Soplicy jako o ich autorze. Pisali zaś zupełnie innym, bardziej rzeczowym tonem, mówiąc rzeczy ważniejsze niż nieco później, kiedy Rzewuski ujawnił się ze swoim autorstwem. Wypada pożałować, że chwiejny jak zawsze - hrabia zdecydował się umieścić jednak nazwisko na okładce... Jak zwykle w swoim życiu zepsuł tym cały misterny plan.

W 1841 roku Michał Grabowski pisał jednak do Rzewuskiego:

$\mathrm{Na}$ malarza staropolski trzeba było koniecznie nabożnych i nieliberalnych. Jak chcieć, żeby Magnuszewski, żeby Czajkowski malowali wiernie naszą przeszłość, oni, co zerwali z nią zupełnie w politycznych i religijnych wyobrażeniach? Soplica przeciwnie, nie przestąpi ani na krok za r. 1788 . Nie wahałbym się powiedzieć, że to rozumnie, choćby mnie tysiąc wrzasków ogłuszyło, ale przynajmniej nikt nie zaprzeczy, że to najszczęśliwiej artystycznie ${ }^{40}$.

Grabowski, znający wszakże „prawdziwe” imię twórcy Pamiątek, uznał Soplicę za ich autora, stawiając go na równi z pozostałymi pisarzami i porównując jego talent $\mathrm{z}$ ich talentem. Mówi skutecznie, uchwycił bowiem sedno tego pisarstwa, bo potraktował Soplicę jak autora właśnie; poza tym rozpoznal, jak ważne jest, że to akurat Soplica opowiada. Grabowski popisuje się znakomitym instynktem - to od niego można się dowiedzieć, że bez Soplicy nawet Rzewuski musiałby ponieść dotkliwą klęskę milczenia. Stefan Witwicki mówił o pseudonimie Rzewuskiego jeszcze bardziej wprost: „Pan Soplica jest wielkim twórcą w rzetelnym znaczeniu wyrazu"41. Równie wnikliwym, chociaż znacznie bardziej krytycznym obserwatorem okazal się Kraszewski:

Szaleje, kto dla miłości zmarłego zakopuje się z nim w jednym grobie, chybaby sam chciał umrzeć, bo grób mieszkaniem umarłych. Inna jest opłakiwać na mogile, a inna - do niej zstępować z zimnymi trupami ${ }^{42}$.

$\mathrm{Za}$ pomocą takiej nekrofilnej stylistyki potępil pastiszowy chwyt wkładania maski autorskiej człowieka $\mathrm{z}$ epoki minionej, a więc maski

${ }^{40}$ Michała Grabowskiego listy literackie, Kraków 1934, s. 210. Cyt. za: M. Maciejewski, Gawęda..., s. 101.

${ }^{41}$ S. Witwicki, wstęp do:, Pamiątki Soplicy, wyd. 2, Berlin 1841. Cyt. za: D. Świerczyńska, Polski pseudonim..., s. 150.

42 Kraszewski o powieściopisarzach i powieści. Zbiór wypowiedzi teoretycznych i krytycznych, Warszawa 1962, s. 138. Cyt. za: M. Maciejewski, Gawęda..., s. 104. 
śmiertelnej43. Mówi Kraszewski o samobójstwie polskich pisarzy, którzy pooddawali swoje glosy postaciom $\mathrm{z}$ minionej epoki - np. Soplicy. Ma im za złe, że przybrali inne imiona, przez to zmienili język, a w konsekwencji również swój pogląd na rzeczywistość. Jak widać, podobne gesty traktował Kraszewski bardzo poważnie, a wręcz egzystencjalnie.

Kiedy za namową Mickiewicza Rzewuski zasiadł w 1830 roku nad czystą kartką papieru, kiedy musiał zamilknąć (na szczęście nie jest prawdą, że „dla gawędziarza milczenie jest swego rodzaju śmiercią"44), aby w nienaturalnych dla siebie i dla gatunku, który miał właśnie stworzyć, warunkach rozpocząć pracę nad Pamiqutkami Soplicy, znalazł się w bardzo dwuznacznej sytuacji. Można powiedzieć, że byłby Rzewuski ludowym folklorystą, gdyby swoich pieśni sam nie musiał sobie śpiewać45. Andrzej Waśko określa tę podwójną rolę jako „zmienną grę dystansu i utożsamienia pomiędzy podmiotem czynności twórczych a narratorem"46. Ta uwaga dobrze oddaje istotę pseudonimu, w którym nie chodzi o banalne przypisywanie autorowi rzeczywistemu wszystkiego tego, co robi i myśli pseudonim; nie chodzi o obarczanie go całym światopoglądem pseudonimu. Takie próby były(by) nieporozumieniem, a wynikały(by) $\mathrm{z}$ niezrozumienia istoty pseudonimu. Co w takim razie powinien zagwarantować dobry pseudonim? Płynność granicy pomiędzy autorem a „auktorem”47, niefortunność wszelkich ostrych ustaleń dotyczących rozdziału myśli i poglądów tych obu imion własnych. Dobry pseudonim komplikuje również relacje pomiędzy fikcją a tym, co zwykło się nazywać rzeczywistością:

Gawęda pojawia się niejako na granicy: niewyraźnej i nigdy do końca nie ustalonej granicy pomiędzy życiem a literaturą. Czyli tam, gdzie zawsze jest miejsce prawdziwej poezji48.

Warto uzupełnić w duchu Hydena White'a, idąc za przykładem Rzewuskiego: gawęda pojawia się tam, gdzie jest miejsce prawdziwej poezji i równie prawdziwej historii.

Dwuznaczność Soplicy, jego bycie pomiędzy światem fikcji i rzeczywistości, autentyku i fałszerstwa, przeciętności i kuriozum, ma swoje odzwierciedlenie w niejednoznacznej postawie życiowej samego Rzewu-

${ }^{43}$ M. Maciejewski, Gawęda..., s. 104.

${ }^{44}$ M. Maciejewski, Gawęda o gawędzie..., s. 13.

45 A. Waśko, Romantyczny sarmatyzm. Tradycja szlachecka w literaturze polskiej lat 1831-1863, Kraków 1995, s.108.

${ }^{46} \mathrm{~A}$. W aśko, Romantyczny sarmatyzm, s. 108.

$47 \mathrm{Z}$ łac. auctor to sprawca czynności twórczych. Używam rozróżnienia autora $\mathrm{i}$ auktora dla rozpoznania dwóch imion: metrykalnego i pseudonimowego.

${ }^{48} \mathrm{~A}$. Waśko, Gawęda szlachecka $w$ literaturze polskiej, wstęp do: Romantyczna gawęda szlachecka. Antologia, Kraków 1999, s. XIII. 
skiego. Można by przywołać na poparcie tej tezy wypadki z całego, momentami schizofrenicznego życia pisarza, ale wystarczy powtórzyć spostrzeżenie, jakie poczynił Andrzej Waśko, iż

wielowarstwowość przekazu literackiego miała swój odpowiednik obyczajowy w podwójnej roli, jaką Rzewuski - wykształcony arystokrata - odgrywal na salonach, pozując na sarmackiego prostaczka ${ }^{49}$.

Bo Rzewuski niejedno miał imię, a historia uczy, że różne osoby znały kilka co najmniej postaci legitymujących się tym imieniem - zawsze własnym. Bo mowa to teatr, w którym jednostka $\mathrm{z}$ jednej strony nie może odsłonić swojej nagiej twarzy, z drugiej zaś nie potrafi nigdy swojej twarzy całkowicie i skutecznie ukryć. W tym teatrze widzowie nigdy nie mogą być pewni, czy widzą prawdziwą twarz aktora, czy prawdziwą twarz bohatera. Nie powinni oni w związku z tym ryzykować stwierdzeń typu: to imię nie jest prawdziwe. Nie ma nagiej twarzy Henryka Rzewuskiego, w którą tak bardzo wierzyli badacze jego twórczości. Rzewuski pozbył się jej, kiedy zdecydował się poddać przeznaczeniu swojego życia namiętności pisania. Gdzież Rzewuski mógł znaleźć lepsze narzędzie do przekształcenia swojego imienia niż język! Szansę, którą swoją propozycją podarował mu Mickiewicz, wykorzystał znakomicie - zrobił dobry użytek z języka pisanego, w którym istoty pseudonimu nie psuł już swoją własną twarzą gawędziarza.

Wydaje się, że po tych uwagach należałoby powiedzieć raczej: „Seweryn Soplica jako autor Pamiatek Soplicy Henryka Rzewuskiego".

$\mathrm{Na}$ zakończenie pozwolę sobie raz jeszcze zadać pytanie: dlaczego pseudonim? Bo „gdyby [Rzewuski - P.D.] występowal tylko w swoim imieniu, nie mógłby niczego ofiarować innym"50.

49 A. Waśko, Romantyczny sarmatyzm, s. 109.

${ }^{50}$ M. Markowski, Pragnienie $i$ batwochwalstwo, s. 41. Notabene kuszące wydaje się zinterpretowanie pseudonimu i wzajemnych, skomplikowanych relacji zachodzących pomiędzy Rzewuskim a „Rzewuskim” przez pryzmat propozycji Markowskiego zawartych w eseju Relacja $i$ religia (Pragnienie..., s. 32-41). Jest to jednak zamiar zdecydowanie wykraczający poza wąskie, tekstualne ramy tej wypowiedzi. 